\title{
Efficacy of Using Lactic Acid Bacillus on Productive Parameters of Babcock B300 Laying Hens Strain
}

\author{
Mahdi Salih Mohammad Al-Kerwi ${ }^{1, a)}$, Moustafa Abed - Almajeed ${ }^{2}$, Omar Mardenli $^{2, b)}$, Faez Saleh \\ Mohammad $^{1}$, Ammar subhy Shaker ${ }^{1}$, Hawraa G.T.Al-Shebani ${ }^{1}$ and Asmaa Mohammed D. K ${ }^{1, c)}$ \\ ${ }^{I}$ Faculty of Agriculture, University of Al-Qadisiah, Iraq. \\ ${ }^{2}$ Faculty of Agriculture, University of Aleppo, Syria. \\ a) Corresponding Author: mahdi.mohammad@qu.edu.iq \\ b) omardenli@gmail.com \\ c)ama529365@gmail.com
}

Received : $15 / 11 / 2021$

Acceptance : 29/12/2021

Available online: $31 / 12 / 2021$

\begin{abstract}
This research was carried out in the Research Center of the Faculty of Agriculture in Al-Muslimiya, 240 hybrid Babcock B300 female laying hens were randomly distributed since the first day of the experiment into four independent groups. Each group included 60 birds according to three replicates (20 birds in each replicate). Lactic acid bacillus was added to the feed mixture according to three levels $(50 \mathrm{mg} / \mathrm{kg}$; B group, $100 \mathrm{mg} / \mathrm{kg} ; \mathrm{C}$ group and 150 $\mathrm{mg} / \mathrm{kg}$; D group), while the first group was considered as a control group (A group) and was without additions. During the production period, the results showed that the addition of lactic acid bacillus led to significant differences $(p<0.03)$ in the egg production and shell thickness compared with the control group. The additions did not affect the egg weight and feed consumption rate as well as the feed conversion ratio. The birds of the third group (C group) showed clear superiority in various productive traits compared to others in the other groups throughout the productive period followed by the birds of group D and then group B. The current study concluded that adding $100 \mathrm{mg} / \mathrm{kg}$ lactic acid bacillus to the feed mixtures for laying hens will contribute to raising the productive efficiency of laying hens and improving egg specifications.
\end{abstract}

Keywords. Lactic acid bacillus, Laying hens, Productive parameters.

\section{INTRODUCTION}

The development of poultry science is in fact linked to the interplay of many paths, the most important of which are genetics, animal husbandry, physiology and nutrition $[1,2]$.

The goals that poultry breeders aspire to is to increase production in quantity and quality and to improve the health status depending on the nutrition and care means [3-5]. The breeders turned to the intensive use of antibiotics in feeding as therapeutic doses and growth stimulants. Accordingly, this led to the development of bacterial strains resistant to antibiotics [6], which made the antibiotics lose their therapeutic role and become dangerous for the health of poultry [7] and humans [8]. Therefore, it was necessary to search for natural alternatives to avoid the harmful effects of antibiotics [9].

Recent studies have revealed that the use of lactic acid promotes beneficial bacteria in the intestinal flora of birds, and works to restore the bacterial balance when adult birds are exposed to stress factors such as high temperatures and pathological injuries [10]. It was noted that the lactobacilli led to an increase in the numbers of beneficial bacteria in the gut flora and a decrease in broodiness [11-14]. Several studies have shown that the promotion of beneficial bacteria within the gastrointestinal tract of laying hens has an important role in improving egg production and quality characteristics [15-18], as well as the haematological indexes of blood [19-21], and feed consumption rate [22,23]. Herein, the use of lactobacillus in feed mixtures for laying hens is still under study, and the reported results are differential. In our study, we aimed to test levels of addition of lactic acid bacillus in terms of its positive impact on the production and blood indicators, especially in the local conditions of the Syrian Arab country.

\section{MATERIALS AND METHODS}

\section{- $\quad$ Experimental Design}

The experiment followed a completely randomized block design (CRD), 240 laying hens of Babcock hybrid strain were randomly distributed since the first day of the experiment into four independent and identical groups, each group included 60 birds according to three replicates of 20 birds in every replicate. Lactobacillus was added across three treatments of feed 
mixture (50 mg/kg; B group, $100 \mathrm{mg} / \mathrm{kg}$; C group and $150 \mathrm{mg} / \mathrm{kg}$; D group), while The first group (A group) is designated as a control group (no additions). The following parameters have been studied:

1. Evolution of the egg production $(\%)$ : The cumulative egg production (egg/bird) was calculated for each replicate starting from the rate of egg production reaching $50 \%$ of the peak productivity until the end of the breeding period at the age of 32 weeks.

2. Evolution of the egg weight average: the weight was measured using a high-accuracy digital sensitive scale.

3. The thickness of the eggshell: the thickness was measured using a micrometer.

4. The average of feed consumption during the production stabilization period (28-32'th weeks): It was calculated weekly and for the entire period of bird breeding by weighing the amount of feed provided to the birds of each group at the beginning of each week, then weighing the amount of feed remaining in the feeders of each group at the end each week. Next, the average feed consumption per bird was calculated, concerning the exclusion of the quantities of feed not consumed due to dead birds, as indicated by [24], with some modifications.

5. Feed conversion ratio (FCR) during the production stabilization period during the $28-23$ 'th weeks of age: the FCR was calculated weekly during the production stabilization period.

\section{- System of Care and Nutrition}

The groups of laying hens were kept in a barn $\left(10 \times 50 \mathrm{~m}^{2}\right)$ built of reinforced concrete with a gabled surface painted from the inside with lime with a direction of east to west). Ventilation was designed across through side windows. Before starting the work, the barn was cleaned, disinfected with formalin and ventilated for 24 hours.

The probiotic (Lactobacillus probiotic) was obtained from a laboratory of the Faculty of Agriculture, Cairo University, Egypt. One kilogram (powder) of Lactobacillus probiotic contains the following:

- $10^{10}$ Lactobacillus acidophilus.

$-10^{10}$ Bacillus subtilus.

- $10^{10}$. Lactobacillus casei

Table 1 shows the composition of the feed mixture used in feeding according to the standard needs of laying hens.

TABLE 1. Composition of the feed mixture provided to the birds of the experimental groups.

\begin{tabular}{cccc}
\hline $\begin{array}{c}\text { Fodder } \\
\text { Component }\end{array}$ & $\mathbf{1 - 6 0}$ days & $\mathbf{6 1 - 1 5 0}$ days & $\mathbf{1 5 1 - 2 2 4}$ days \\
\hline Maize & 69 & 67 & 61.6 \\
Soybean meal & 25 & 25 & 14.8 \\
Meat and bone & 2 & 2 & - \\
meal & & & \\
Dicalcium & 1.5 & 1.5 & 10.8 \\
Phosphate & & & \\
Calcium & 1 & 1 & - \\
carbonate & 0.5 & 0.5 & 0.3 \\
NaCl & 0.5 & 0.5 & 0.1 \\
Premix Vitamins & 0.5 & 0.5 & 0.1 \\
Premixes & - & 2 & 7 \\
Limestone & - & - & 0.1 \\
Methionine & - & - & 0.1 \\
Choline chloride & & &
\end{tabular}

Table 2 shows the chemical composition of the aforementioned feed mixture.

TABLE 2. Chemical composition of the feed mixture provided to the birds of the experimental groups.

\begin{tabular}{cccc}
\hline & $\mathbf{1 - 6 0}$ days & 61-150 days & 151-224 days \\
\hline Energy $(\mathrm{kcal})$ & 2900 & 2800 & 2701 \\
Components $(\%)$ & & & \\
Protein & 21.00 & 21.00 & 16.30 \\
Calcium & 1.05 & 1.00 & 2.00 \\
Phosphorous & 0.48 & 0.45 & 0.45 \\
Sodium & 0.18 & 0.17 & 0.16 \\
Chlorine & 0.20 & 0.19 & 0.18 \\
Lysine & 1.20 & 1.00 & 0.85 \\
Methionine + & 0.83 & 0.70 & 0.68 \\
Cysteine & 1.26 & 1.05 & 0.92 \\
Arginine & 0.23 & 0.21 & 0.20 \\
Tryptophan & 0.80 & 0.70 & 0.60 \\
Threonine $\%$ & & &
\end{tabular}




\begin{tabular}{cccc}
\hline & 1-60 days & 61-150 days & 151-224 days \\
\hline Leucine & 1.55 & 1.30 & 1.05 \\
Isoleucine & 1.00 & 0.83 & 0.77 \\
Linoleic Acid & 1.40 & 1.40 & 1.00 \\
\hline
\end{tabular}

\section{- $\quad$ Statistical Analysis}

The data was subjected to a typesetting process using a sophisticated computer. The data were analyzed according to the maximum likelihood method (ML) by means of analysis of variance(ANOVA). The significant differences among the means were monitored by the least significant difference (LSD) at $<0.05$ using the [25], software.

\section{- $\quad$ Egg Production (\%)}

\section{RESULTS AND DISCUSSION}

The results (Table 3) indicate that the level of egg production at the 21 'th week was close among the groups with an insignificant improvement in the $\mathrm{B}$ and $\mathrm{C}$ groups (50.67\% and $50.00 \%$ respectively) compared to the control group (A group; $47.92 \%$ ).

Starting from the 22 'th week down to the end of the care period ( 32 'th week), the previous groups continued to outperform.

The highest average egg production in the 27 'th week was at the $\mathrm{C}$ group $(93.33 \%)$ followed by the D group (89.65\%), while the level of egg production was in similarity in the B and A groups (85.35\% and 84.19\%, respectively).

It should be noted that the $\mathrm{C}$ group outperformed the rest of the groups during the most weeks of egg production. Upon the 23 'th week, the level of egg production reached $94.71 \%$. In this context, our results agreed with the findings of [14-16], while the results didn't come in the line with the findings of [17].

TABLE 3. Egg production (\%)at the various groups of hens fed on bacillus lactic acid feed mixture (Mean $\pm \mathrm{Se})$.

\begin{tabular}{|c|c|c|c|c|c|}
\hline \multirow{2}{*}{ Age (week) } & \multicolumn{4}{|c|}{ Groups } & \multirow{2}{*}{ Prob. } \\
\hline & $\mathbf{A}$ & B & $\mathbf{C}$ & D & \\
\hline 21 & $\begin{array}{c}\mathrm{b} \\
47.92 \pm 2.69\end{array}$ & $\begin{array}{c}\mathrm{B} \\
46.96 \pm 3.31\end{array}$ & $\begin{array}{c}\mathrm{B} \\
50.67 \pm 2.33\end{array}$ & $\begin{array}{c}b \\
50.00 \pm 1.52\end{array}$ & N.S \\
\hline 22 & $\begin{array}{c}\mathrm{b} \\
63.97 \pm 3.47\end{array}$ & $\begin{array}{c}\text { B } \\
62.48 \pm 3.05\end{array}$ & $\underset{72.16 \pm 3.60}{A}$ & $\begin{array}{c}\mathrm{a} \\
70.70 \pm 1.569\end{array}$ & 0.01 \\
\hline 23 & $\begin{array}{c}b \\
71.94 \pm 2.32\end{array}$ & $\begin{array}{c}\mathrm{Ab} \\
77.50 \pm 2.56\end{array}$ & $\begin{array}{c}\mathrm{A} \\
81.08 \pm 3.86\end{array}$ & $\begin{array}{c}\mathrm{a} \\
79.38 \pm 5.06\end{array}$ & 0.02 \\
\hline 24 & $\begin{array}{c}\mathrm{b} \\
75.98 \pm 0.49\end{array}$ & $\begin{array}{c}\mathrm{Ab} \\
83.18 \pm 2.71\end{array}$ & $\begin{array}{c}\mathrm{A} \\
86.39 \pm 4.15\end{array}$ & $\begin{array}{c}a b \\
82.72 \pm 4.69\end{array}$ & 0.04 \\
\hline 25 & $\begin{array}{c}\mathrm{b} \\
78.15 \pm 1.68\end{array}$ & $\begin{array}{c}\mathrm{Ab} \\
85.14 \pm 3.09\end{array}$ & $\begin{array}{c}\mathrm{A} \\
88.04 \pm 3.04\end{array}$ & $\begin{array}{c}\mathrm{a} \\
87.89 \pm 4.68\end{array}$ & 0.01 \\
\hline 26 & $\begin{array}{c}\mathrm{b} \\
80.11 \pm 1.83\end{array}$ & $\begin{array}{c}\mathrm{Ab} \\
87.10 \pm 4.42\end{array}$ & $\begin{array}{c}\mathrm{A} \\
91.37 \pm 1.37\end{array}$ & $\begin{array}{c}\mathrm{a} \\
87.89 \pm 1.85\end{array}$ & 0.01 \\
\hline 27 & $\begin{array}{c}b \\
84.19 \pm 5.07\end{array}$ & $\begin{array}{c}\mathrm{A} \\
85.35 \pm 6.08\end{array}$ & $\begin{array}{c}\mathrm{A} \\
93.33 \pm 3.33\end{array}$ & $\frac{a}{89.65 \pm 0.18}$ & 0.001 \\
\hline 28 & $\begin{array}{c}b \\
84.07 \pm 1.72\end{array}$ & $\begin{array}{c}\text { B } \\
85.14 \pm 4.59\end{array}$ & $\begin{array}{c}\mathrm{A} \\
93.04 \pm 1.54\end{array}$ & $\frac{\mathrm{a}}{91.31 \pm 1.84}$ & 0.001 \\
\hline 29 & $\begin{array}{c}b \\
84.04 \pm 2.12\end{array}$ & $\begin{array}{c}\text { B } \\
87.10 \pm 4.416\end{array}$ & $\underset{93.04 \pm 1.55}{\mathrm{~A}}$ & $\frac{\mathrm{a}}{91.32 \pm 3.55}$ & 0.004 \\
\hline 30 & $\begin{array}{c}b \\
86.04 \pm 1.852\end{array}$ & $\begin{array}{c}\text { B } \\
84.93 \pm 1.74\end{array}$ & $\begin{array}{c}\mathrm{A} \\
93.04 \pm 1.54\end{array}$ & $\begin{array}{c}\mathrm{a} \\
91.31 \pm 1.84\end{array}$ & 0.02 \\
\hline 31 & $\begin{array}{c}\mathrm{b} \\
87.99 \pm .25\end{array}$ & $\begin{array}{c}\text { B } \\
86.69 \pm 2.19\end{array}$ & $\begin{array}{c}\mathrm{A} \\
94.71 \pm .29\end{array}$ & $\begin{array}{c}\mathrm{a} \\
91.40 \pm 1.68\end{array}$ & 0.01 \\
\hline 32 & $\begin{array}{c}\mathrm{b} \\
84.04 \pm 2.12\end{array}$ & $\begin{array}{c}\mathrm{B} \\
86.90 \pm 1.36 \\
\end{array}$ & $\begin{array}{c}\mathrm{A} \\
91.37 \pm 1.37\end{array}$ & $\begin{array}{c}\mathrm{a} \\
93.16 \pm 1.58\end{array}$ & 0.001 \\
\hline
\end{tabular}

A: control, B:50mg/kg, C:100 mg/kg, D: $150 \mathrm{mg} / \mathrm{kg}$, NS: not significant, ${ }^{\mathrm{a}, \mathrm{b}}$ Means in the same row with no common superscripts are significantly different $(\mathrm{P}<0.05)$

\section{- $\quad$ Egg Weight}

The results shown in the Table 4 indicate that the egg weight in the different groups of birds was close during the productive period without significant differences. The values in the middle of the productive period at the end of the 27 'th 
week were $55.26 \mathrm{~g}, 55.97 \mathrm{~g}$ and $55.33 \mathrm{~g}$, respectively (B, C and D groups) while the value in the control group reached 55.67 g.

The convergence in the egg weight continued down to the end of the 32 'th week in all the studied groups. The current results agreed with the results obtained by [26], whereas the results of [27], were opposite to ours.

TABLE 4. Means of egg production at the various groups of hens fed on bacillus lactic acid feed mixture (Mean $\pm \mathrm{Se}$ ).

\begin{tabular}{|c|c|c|c|c|c|}
\hline \multirow{2}{*}{$\begin{array}{c}\text { Age } \\
\text { (week) }\end{array}$} & \multicolumn{4}{|c|}{ Groups } & \multirow{2}{*}{ Prob. } \\
\hline & $\mathbf{A}$ & B & $\mathbf{C}$ & D & \\
\hline 21 & $47.26 \pm 0.45$ & $48.20 \pm 1.05$ & $47.30 \pm 0.40$ & $48.06 \pm 0.77$ & N.S \\
\hline 22 & $50.33 \pm 0.67$ & $50.90 \pm 0.64$ & $51.76 \pm 0.93$ & $51.36 \pm 0.35$ & N.S \\
\hline 23 & $51.26 \pm 0.81$ & $51.86 \pm 0.68$ & $52.83 \pm 0.87$ & $52.90 \pm 0.45$ & N.S \\
\hline 24 & $53.13 \pm 0.66$ & $53.66 \pm 0.40$ & $53.57 \pm 0.0 .43$ & $54.16 \pm 0.80$ & N.S \\
\hline 25 & $54.43 \pm 0.65$ & $54.36 \pm 0.43$ & $55.00 \pm 0.79$ & $55.26 \pm 0.12$ & N.S \\
\hline 26 & $55.20 \pm 0.50$ & $54.90 \pm 0.51$ & $55.50 \pm 0.81$ & $55.67 \pm 1.02$ & N.S \\
\hline 27 & $55.67 \pm 0.39$ & $55.26 \pm 0.37$ & $55.97 \pm 0.66$ & $56.33 \pm 0.84$ & N.S \\
\hline 28 & $56.23 \pm 0.56$ & $55.80 \pm 0.36$ & $56.60 \pm 0.88$ & $56.97 \pm 0.75$ & N.S \\
\hline 29 & $57.83 \pm 0.52$ & $57.06 \pm 0.43$ & $57.56 \pm 0.43$ & $57.46 \pm 0.76$ & N.S \\
\hline 30 & $58.33 \pm 0.68$ & $58.03 \pm 0.52$ & $58.86 \pm 1.08$ & $58.40 \pm 0.70$ & N.S \\
\hline 31 & $59.26 \pm 0.99$ & $59.06 \pm 0.85$ & $60.56 \pm 1.44$ & $59.46 \pm 1.19$ & N.S \\
\hline 32 & $60.60 \pm 1.21$ & $60.00 \pm 1.15$ & $61.16 \pm 1.70$ & $60.73 \pm 1.38$ & N.S \\
\hline
\end{tabular}

A: control, B:50mg/kg, C:100 mg/kg, D: $150 \mathrm{mg} / \mathrm{kg}, \mathrm{NS}:$ not significant,

\section{- $\quad$ Egg Shell Thickness}

Table 5 shows the results of eggshell thickness in the various groups of birds. The results indicate that the differences at the 21 'th week of breeding were not significant, with an improvement in the B and C groups compared with the control group. With the progression in the productive period, the thickness of the eggshell increased significantly at the 22 'th week $(\mathrm{P}<0.05)$ at the $\mathrm{B}$ and $\mathrm{C}$ groups compared to the control group, while the differences were not significant between the B and A groups. At the 23 'th week, it was observed that the additions led to a significant improvement $(\mathrm{P}<0.04)$ in the thickness of the eggshell in these groups compared with the control group, while the differences were not significant across the B group compared with the birds of the control group, as the values were $0.352 \mathrm{~mm}, 0.361 \mathrm{~mm}$ and $0.358 \mathrm{~mm}$, respectively compared to the control group $(0.344 \mathrm{~mm})$. The positive effect of the additives was confirmed at the 24,25 and 26 'th weeks noting that the increase in the thickness of the shell in those groups was not significant at the 26 'th week compared to the control group, but what reinforces the positive effect of the aforementioned additives is the results of the statistical analysis in the remaining weeks $(29,30,31$ and 32 'th weeks).

The reason for the increased thickness of the eggshell in the previous groups may be due to the secretion of lactic acid by the lactic acid bacilli, which in turn improves the absorption of calcium and phosphorous in the alimentary canal [28]. The results of the current study are parallel to those of [14,16], while the results contradict those of [19].

TABLE 5. Means of egg shell thickness at the various groups of hens fed on bacillus lactic acid feed mixture (Mean $\pm \mathrm{Se})$.

\begin{tabular}{cccccc}
\hline Age & \multicolumn{4}{c}{ Groups } & Prob. \\
\cline { 2 - 6 } (week) & $\mathbf{A}$ & $\mathbf{B}$ & $\mathbf{C}$ & $\mathbf{D}$ & \\
\hline 21 & $\mathrm{~b}$ & $\mathrm{~b}$ & $\mathrm{~b}$ & $\mathrm{~b}$ & \multirow{2}{*}{ N.S } \\
& $0.349 \pm 0.004$ & $0.346 \pm 0.002$ & $0.354 \pm 0.003$ & $0.358 \pm 0.006$ & \\
22 & $\mathrm{~b}$ & $\mathrm{~B}$ & $\mathrm{a}$ & $\mathrm{a}$ & 0.05 \\
& $0.346 \pm 0.002$ & $0.440 \pm 0.001$ & $0.369 \pm 0.002$ & $0.361 \pm 0.007$ & \\
23 & $\mathrm{~b}$ & $\mathrm{a}$ & $\mathrm{a}$ & $\mathrm{a}$ & 0.04 \\
& $0.344 \pm 0.003$ & $0.352 \pm 0.010$ & $0.361 \pm 0.006$ & $0.358 \pm 0.005$ & \\
24 & $0.345 \pm 0.006$ & $0.352 \pm 0.005$ & $0.375 \pm 0.006$ & $0.371 \pm 0.007$ & 0.04 \\
& $\mathrm{~b}$ & $\mathrm{~b}$ & $\mathrm{a}$ & $\mathrm{a}$ & 0.008 \\
25 & $0.351 \pm 0.002$ & $0.351 \pm 0.004$ & $0.364 \pm 0.003$ & $0.373 \pm 0.007$ & 0.008 \\
& $\mathrm{~b}$ & $\mathrm{ab}$ & $\mathrm{a}$ & $\mathrm{a}$ & \\
26 & $0.349 \pm 0.001$ & $0.355 \pm 0.004$ & $0.367 \pm 0.007$ & $0.366 \pm 0.003$ & 0.01 \\
& $\mathrm{~b}$ & $\mathrm{~b}$ & $\mathrm{a}$ & $\mathrm{a}$ & \\
27 & $0.351 \pm 0.003$ & $0.351 \pm 0.002$ & $0.362 \pm 0.003$ & $0.369 \pm 0.003$ & 0.01 \\
& & & & & \\
28 & $0.353 \pm 0.001$ & $0.352 \pm 0.003$ & $0.368 \pm 0.003$ & $0.367 \pm 0.003$ & 0.01 \\
& $\mathrm{~b}$ & $\mathrm{~b}$ & $\mathrm{~b}$ & $\mathrm{a}$ & \\
29 & $0.352 \pm 0.002$ & $0.351 \pm 0.001$ & $0.353 \pm 0.001$ & $0.363 \pm 0.004$ & 0.002 \\
30 & $\mathrm{~b}$ & $\mathrm{~b}$ & $\mathrm{a}$ & $\mathrm{a}$ & 0.001 \\
\hline
\end{tabular}




\begin{tabular}{cccccc} 
& $0.350 \pm 0.002$ & $0.354 \pm 0.002$ & $0.376 \pm 0.004$ & $0.370 \pm 0.003$ & \\
31 & $\mathrm{~b}$ & $\mathrm{~b}$ & $\mathrm{a}$ & $\mathrm{a}$ & \multirow{2}{*}{0.006} \\
& $0.352 \pm 0.003$ & $0.353 \pm 0.002$ & $0.370 \pm 0.003$ & $0.372 \pm 0.002$ & \\
32 & $\mathrm{~b}$ & $\mathrm{~b}$ & $\mathrm{ab}$ & $\mathrm{a}$ & \\
& $0.351 \pm 0.001$ & $0.349 \pm 0.001$ & $0.363 \pm 0.004$ & $0.373 \pm 0.005$ & 0.0001 \\
\hline
\end{tabular}

A: control, B:50mg/kg, C:100 mg/kg, D: $150 \mathrm{mg} / \mathrm{kg}$, NS: not significant, NS: not significant, ${ }^{\mathrm{a}, \mathrm{b}}$ Means in the same row with no common superscripts are significantly different $(\mathrm{P}<0.05)$

\section{- $\quad$ Feed Consumption}

The results (Tables 6 and 7) indicate that the mentioned food additives did not have a clear effect on the rates of feed consumption and FCR during the period (28 to 32 'th weeks), as the results were close. To note, many studies did not find an effect of probiotics on feed consumption and FCR, as is the case with [13,27].

TABLE 6. Means of feed consumption during the production stabilization period at the various groups of hens fed on bacillus lactic acid feed mixture (Mean \pm Se).

\begin{tabular}{cccccc}
\hline \multirow{2}{*}{$\begin{array}{c}\text { Age } \\
\text { (week) }\end{array}$} & \multicolumn{4}{c}{ Groups } & \multirow{2}{*}{ Prob. } \\
\cline { 2 - 5 } & $\mathbf{A}$ & $\mathbf{B}$ & $\mathbf{C}$ & $\mathbf{D}$ & \\
\cline { 2 - 5 } 28 & $726.67 \pm 10.33$ & $732.67 \pm 23.87$ & $742.33 \pm 12.12$ & $724.33 \pm 24.88$ & N.S \\
29 & $770.00 \pm 12.76$ & $752.00 \pm 10.44$ & $728.33 \pm 14.31$ & $758.33 \pm 24.45$ & N.S \\
30 & $779.33 \pm 23.77$ & $742.67 \pm 21.05$ & $766.67 \pm 7.88$ & $798.00 \pm 17.92$ & N.S \\
31 & $772.00 \pm 12.28$ & $795.33 \pm 23.91$ & $741.00 \pm 18.52$ & $726.00 \pm 24.84$ & N.S \\
32 & $769.33 \pm 21.73$ & $801.33 \pm 40.68$ & $757.33 \pm 20.98$ & $792.33 \pm 29.13$ & N.S \\
\hline
\end{tabular}

A: control, B:50mg/kg, C:100 mg/kg, D: $150 \mathrm{mg} / \mathrm{kg}, \mathrm{NS}:$ not significant

Other studies have proven an impact in this regard (19 and 1).

TABLE 7. Means of FCR during the production period stabilization at the various groups of hens fed on bacillus lactic acid (Mean \pm Se).

\begin{tabular}{cccccc}
\hline \multirow{2}{*}{$\begin{array}{c}\text { Age } \\
\text { (week) }\end{array}$} & \multicolumn{4}{c}{ Groups } & Prob. \\
\cline { 2 - 5 } & $\mathbf{A}$ & B & C & D & \\
\hline 28 & $1.84 \pm 0.04$ & $1.87 \pm 1.10$ & $1.86 \pm 0.02$ & $1.81 \pm 0.06$ & N.S \\
29 & $1.90 \pm 0.03$ & $1.88 \pm 0.02$ & $1.80 \pm 0.02$ & $1.87 \pm 0.04$ & N.S \\
30 & $1.91 \pm 0.08$ & $1.83 \pm 0.07$ & $1.86 \pm 0.02$ & $1.95 \pm 0.06$ & N.S \\
31 & $1.86 \pm 0.03$ & $1.92 \pm 0.07$ & $1.75 \pm 0.06$ & $1.74 \pm 0.02$ & N.S \\
32 & $1.81 \pm 0.01$ & $1.91 \pm 0.10$ & $1.77 \pm 0.04$ & $1.86 \pm 0.08$ & N.S \\
\hline
\end{tabular}

A: control, B:50mg/kg, C:100 mg/kg, D: 150mg/kg, NS: not significant

\section{CONCLUSION}

It concluded that adding lactic acid bacillus with the level $100 \mathrm{mg} / \mathrm{kg}$ to the feed mixtures of laying hens contribute to raising the egg production and shell thickness of laying hens.

\section{REFERENCES}

[1] Mardenli, O. 2021. The Progeny test of Friesian sires for milk traits by using the contemporary comparison method. Rev Colombiana Cienc Anim. Recia. enero-junio; 13(1):e747.

[2] Mohammad, M. S., Mardenli, O., Al-TAwash, A.S.A.2021. Evaluation of The Cryopreservation Technology of Poultry Sperm: A Review Study. IOP Conf. Series: Earth and Environmental Science 735 (2021) 012016

[3] Al-Kerwi Mohammad, M.S., Amin Al-Tawash, A.S., Salah Almrsomi, T.2020. Comparison the Effect of Adding Waterly Extract of Black Seeds (Nigella Sativa), Chamomile and Fenugreek with Drinking Water on Productive Performance for Broiler. IOP Conference Series: Earth and Environmental Sciencethis, 553(1), 012043

[4] AL-Tawash, A.S.A., Suwaihi, T.A., Mohammad, M.S., Mohsen, A.A.2020. Beneficial effects of chrysin and ginger on blood biochemical parameters, hematology and immune response of broilers. Plant Archivesthis , 2020, 20, pp. 215-219

[5] Almrsomi, T.S., Areaaer, A.H., Mohammad, M.S.2021. Influence of addition different levels of ginger powder in diet on productive performance of broiler ross. Indian Journal of Ecologythis , 2021, 48, pp. 6-9

[6] Collignon, P.J., 1999- Vancomycin - resistant entrococci and use of avoparcin in animal feed : Is there alink ? Med .S. Aust .171: 144-146.

[7] Thorns, C.J., 2000- Bacterial food - borne Zoonoses . Revue Scientifque et technique . 19:226-239.

[8] Sahin, O. ,T.Y. Morislita, and Q. Zhang .2002- Camylobacter Colonization in Poultry: Sources of infection modes and transmission .Anim. Health Res. Rev ., 3:95-105.

[9] Verstegen, M.W., and B.A. WIlliams ., 2002- Alternatives to the use of antibiotics as growth promoters for monogastric animals . Anim. Biotechnol 13:113-27.

[10] Griggs, J. P. and J. P. Jacob., 2005- Alternatives to antibiotics for organic poultry production. J. Appl. Poult. Res. 14:750-756. 


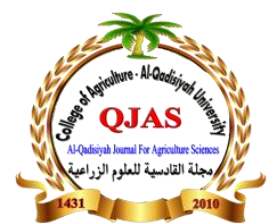

[11] Haddadin, M. S. Y.; S. M. Abdulrahim; N. H. Odetallah AND R. K. Robinson., 1997- A proposed protocol for checking suitability of Lactobacillus acidophilus cultures for use during feeding trials with chickens. Tropic. Sci. 37: 16-20.

[12] Hayirlı A, N. Esenbuğa, M. Macit, M. A. Yörük, A. Yildiz and H. Karaca., 2005- Nutrition practice to alleviate the adverse effects of stress on laying performance, metabolic profile and egg quality in peak producing hens: II. The probiotic supplementation. Asian-Aust. J. Anim. Sci.. Vol 18, No. 12 : 1752-1760.

[13] Yousefi.M and K.Karkoodi., 2007-Effect of Probiotic and Saccharomyces cerevisiae Supplementation on performanace and Egg Quality of Laying Hens.,International of Poultry Science 6(1):52-54.

[14] Panda, A. K., Rama Rao, S. S., Raju, M. V., \& Sharma, S. S. (2007). Effect of probiotic (Lactobacillus sporogenes) feeding on egg production and quality, yolk cholesterol and humoral immune response of White Leghorn layer breeders. Journal of the Science of Food and Agriculture, 88(1), 43-47. doi:10.1002/jsfa.2921

[15] Nahashon, S. N.; H. S. Nakaue and L. W. Mirosh., 1994- Production variables and nutrient retention in single comb white leghorn laying pullets fed diets supplemented with direct fed microbial. Poultry Sci. 73:1699-1711.

[16] Mohan B., Kadirvel R., Bhaskaran M., Natarajan A., 1995- Effect of probiotic supplementation on serum yolk cholesterol and egg shell chickens in layers, Br. Poult. Sci., 36: 799-803.

[17] Balevi, T., U.S. Uçan, B. Coşun, V. Kurtoğu \& İ.S. çetingül (2001) Effect of dietary probiotic on performance and humoral immune response in layer hens, British Poultry Science, 42:4, 456-461, DOI: 10.1080/00071660120073133

[18] Hunton, P., 2004-America's Leading. World Poultry Congress Hears Research Reports. p: 1-4.

[19] Siam S. M. and Alm El-Dein A. K., 2004- Influence of using two different levels of probiotics on egg performance, blood and yolk cholesterol of laying hens. Egyptian Poultry Science Journal , 1110-5623.2004.

[20] Zangana, B. S. R and Al-Hajo, N. N. A., 2009- A comparative study on the effect of locally produced probiotic, prebiotic and synbiotic on egg chemical composition and egg serum cholesterol of White Leghorn hens. Journal Egyptian Journal of Nutrition and Feeds. 12:(1). 177-185.

[21] Alkhalf A., M. Alhaj and I. Al-Homidan., 2010-. Influence of probiotic supplementation on blood parameters and growth performance in broiler chickens. Saudi Journal of Biological Sciences 17(3): 219-225.

[22] Tortuero, F., Fernández, E., 1995- Effects of inclusion of microbial cultures in barley-based diets fed to laying hens. Anim. Feed. Sci. Tech. 53:255-265.

[23] Abdulrahim A; M. S. Y. Haddadin A; E. A. R. Hashlamoun A; R. K. Robinson., 1996- The influence of lactobacillus acidophilus and bacitracin on layer performance of chickens and cholesterol content of plasma and egg yolk. British Poultry Science. 37(2): 341-346.

[24] Lehmood, B. A. M., Hadi, M. M. 2013.Effect of humic acid and rosemary on productive and economical traits of Japanese quail birds grown in hot environment. Euphrates Journal of Agriculture Science, 5(4:):64-75

[25] SAS Institute Inc. 2017. SAS/STAT® 14.3 User's Guide. Cary, NC: SAS Institute.

[26] Chen, Y.C. and T.C. Chen., 2003- Effects of commercial probiotic or prebiotic supplementation on production, size and quality of hens egg. Poult. Sci., 82: 330.

[27] Bozkurt Mehmet., Küçükyilmaz Kamil., Ayhan Veysel., Çabuk Metin., Uğur Çatli Abdullah., Erbeyli Tavukçuluk, 2011Performance of layer or broiler breeder hens varies in response to different probiotic preparations. Italian Journal of Animal Science volume 10:e31.

[28] Nickolova M, Penkov D., 2004- Experimental influence of Laktina probiotic on egg laying characteristics, fertility and viability in muscovy duck (Cairina Moshcata). J Cent Eur Agric, 5, 353-358. 